\title{
Activity-Dependent Cleavage of the K-Cl Cotransporter KCC2 Mediated by Calcium-Activated Protease Calpain
}

\author{
Martin Puskarjov, ${ }^{1 \star}$ Faraz Ahmad, ${ }^{1 \star}$ Kai Kaila, ${ }^{1}$ and Peter Blaesse ${ }^{1,2}$ \\ ${ }^{1}$ Department of Biosciences and Neuroscience Center, University of Helsinki, FI-00014 Helsinki, Finland and ${ }^{2}$ Institute of Physiology I, Westfälische \\ Wilhelms-University Münster, D-48149 Münster, Germany
}

The $\mathrm{K}-\mathrm{Cl}$ cotransporter $\mathrm{KCC} 2$ plays a crucial role in neuronal chloride regulation. In mature central neurons, KCC2 is responsible for the low intracellular $\mathrm{Cl}^{-}$concentration $\left(\left[\mathrm{Cl}^{-}\right]_{\mathrm{i}}\right)$ that forms the basis for hyperpolarizing $\mathrm{GABA}_{\mathrm{A}}$ receptor-mediated responses. Fast changes in KCC2 function and expression have been observed under various physiological and pathophysiological conditions. Here, we show that the application of protein synthesis inhibitors cycloheximide and emetine to acute rat hippocampal slices have no effect on total KCC2 protein level and $\mathrm{K}-\mathrm{Cl}$ cotransporter function. Furthermore, blocking constitutive lysosomal degradation with leupeptin did not induce significant changes in KCC2 protein levels. These findings indicate a low basal turnover rate of the total KCC2 protein pool. In the presence of the glutamate receptor agonist NMDA, the total KCC2 protein level decreased to about $30 \%$ within $4 \mathrm{~h}$, and this effect was blocked by calpeptin and MDL-28170, inhibitors of the calcium-activated protease calpain. Interictal-like activity induced by incubation of hippocampal slices in an $\mathrm{Mg}^{2+}$-free solution led to a fast reduction in $\mathrm{KCC} 2$-mediated $\mathrm{Cl}^{-}$transport efficacy in CA1 pyramidal neurons, which was paralleled by a decrease in both total and plasmalemmal KCC2 protein. These effects were blocked by the calpain inhibitor MDL-28170. Taken together, these findings show that calpain activation leads to cleavage of KCC2, thereby modulating GABAergic signaling.

\section{Introduction}

Neuronal plasticity is critically dependent on targeted cleavage of synaptic proteins (Bingol and Sheng, 2011). Specific activation of the intracellular $\mathrm{Ca}^{2+}$-dependent protease calpain by excitatory amino acid signaling confers selective activitydependent cleavage of synaptic substrates and thus plays a pivotal role in regulating neuronal plasticity (Lynch and Baudry, 1984; Siman and Noszek, 1988; Denny et al., 1990; Wu and Lynch, 2006; Liu et al., 2008). Calpain is activated by intracellular $\mathrm{Ca}^{2+}$ and by the neurotrophic factor BDNF and its receptor TrkB, which leads to specific cleavage of synaptic substrates in response to intense synaptic activity under physiological (Zadran et al., 2010a,b) as well as pathophysiological conditions (Kampfl et al., 1997; Zhou and Baudry, 2006), including seizures (Sierra-Paredes et al., 1999; Fujikawa, 2005). Notably, an increased calpain expression has been recently reported in cortical tissue of patients with drug-resistant temporal lobe epilepsy (Feng et al., 2011).

Received Dec. 16, 2011; revised June 29, 2012; accepted July 3, 2012.

Author contributions: K.K. and P.B. designed research; M.P., F.A., and P.B. performed research; M.P., F.A., and P.B. analyzed data; M.P., K.K., and P.B. wrote the paper.

This study was supported by grants from the Academy of Finland (P.B., K.K.), the Sigrid Jusélius Foundation, the Letten Foundation, and the Jane and Aatos Erkko Foundation (K.K.). K.K. is a member of the Finnish Center of Excellence in Molecular and Integrative Neuroscience Research. We thank Britta Haas for excellent technical assistance. The anti-NTD-KCC2 antibody was a generous gift from Dr. Hans Gerd Nothwang (Carl von Ossietzky University, Oldenburg, Germany).

*M.P. and F.A. contributed equally to this work.

Correspondence should be addressed to Prof. Kai Kaila, Department of Biosciences, University of Helsinki, Fl-00014 Helsinki, Finland. E-mail: Kai.Kaila@helsinki.fi

DOI:10.1523/JNEUROSCI.6265-11.2012

Copyright $\odot 2012$ the authors $\quad 0270-6474 / 12 / 3211356-09 \$ 15.00 / 0$
The neuronal targets of calpain are mainly involved in $\mathrm{Ca}^{2+}$ dependent signaling, synaptic architecture, and neurotransmission. These include $\alpha \mathrm{II}$-spectrin (Siman et al., 1984; Nixon, 1986), actin (Villa et al., 1998), glutamate receptors (Bi et al., 1997; Xu et al., 2007), the postsynaptic density-95 protein (Gascón et al., 2008), the $\mathrm{Na}^{+} / \mathrm{Ca}^{2+}$ exchanger (Bano et al., 2005), ankyrinG (Schafer et al., 2009), the voltage-gated sodium channel $\alpha$ subunit (von Reyn et al., 2009), and the plasma membrane $\mathrm{Ca}^{2+}$-ATPase (Pottorf et al., 2006). However, whether calpain plays a role in neuronal $\mathrm{Cl}^{-}$regulation is unknown.

$\mathrm{KCC} 2$ is the principal $\mathrm{Cl}^{-}$extruder in mature central neurons and is responsible for maintaining $\left[\mathrm{Cl}^{-}\right]_{\mathrm{i}}$ below electrochemical equilibrium, a necessary condition for generation of "classical" hyperpolarizing IPSPs (Rivera et al., 1999; Farrant and Kaila, 2007). Moreover, KCC2 plays a major role already at the early stages in the development of excitatory synapses (Khalilov et al., 2011). Notably, cortical pyramidal neurons lacking KCC2 display an aberrant spine morphology in vitro (Li et al., 2007), and overexpression of KCC2 has been shown to induce functional spines in vivo (Fiumelli et al., 2012). In addition, suppression of the expression of KCC2 leads to an increase in the lateral diffusion and a reduced accumulation of AMPA-type glutamate receptors in spines (Gauvain et al., 2011). The above findings imply KCC2 as a key molecule in plasticity of both GABAergic and glutamatergic signaling.

$\mathrm{Ca}^{2+}$-dependent downregulation of $\mathrm{KCC} 2$ protein and $\mathrm{Cl}^{-}$ extrusion occurs under various plasticity-inducing physiological and pathophysiological conditions (e.g., Fiumelli et al., 2005; Lee et al., 2011; for review, see Blaesse et al., 2009; Löscher et al., 2012) and is directly linked to activity-dependent upregulation of 
BDNF/TrkB signaling (Rivera et al., 2002, 2004). Here, we show using hippocampal slices from rat that the total KCC2 protein level and the functional KCC2 pool remain unchanged for at least $4 \mathrm{~h}$ in the absence of protein synthesis. Furthermore, we demonstrate that excitotoxicity induced by the glutamate receptor agonist NMDA as well as interictal-like activity induced by incubation of slices in an $\mathrm{Mg}^{2+}$-free physiological solution, results in calpain-mediated downregulation of KCC2, identifying KCC2 as a novel substrate of calpain. Thus, the present findings point to calpain as a major factor controlling ionic plasticity of GABAergic signaling.

\section{Materials and Methods}

Experiments were approved by the local Animal Ethics Committee of the University of Helsinki.

Drugs. If not indicated otherwise, drugs were from Tocris Bioscience.

Brain slices. Acute $400 \mu \mathrm{m}$ transverse and coronal hippocampal slices were prepared from postnatal day 15-20 male Wistar rats. Before decapitation, anesthesia was induced using halothane (Sigma). Brains were quickly removed and immersed into ice-cold sucrose-based cutting solution containing (in mM): $87 \mathrm{NaCl}, 2.5 \mathrm{KCl}, 0.5 \mathrm{CaCl}_{2}, 25 \mathrm{NaHCO}_{3}, 1.25$ $\mathrm{NaH}_{2} \mathrm{PO}_{4}, 7 \mathrm{MgCl}_{2}, 50$ sucrose, and $25 \mathrm{D}$-glucose, equilibrated with $95 \%$ $\mathrm{O}_{2}$ and $5 \% \mathrm{CO}_{2}$. Slices were cut using a Campden $7000 \mathrm{smz}$ vibrating microtome (Campden Instruments). Before the experiments were started, the slices were allowed to recover at $36^{\circ} \mathrm{C}$ for $1 \mathrm{~h}$ in a solution containing (in mM): $124 \mathrm{NaCl}, 3 \mathrm{KCl}, 2 \mathrm{CaCl}_{2}, 25 \mathrm{NaHCO}_{3}, 1.1$ $\mathrm{NaH}_{2} \mathrm{PO}_{4}, 2 \mathrm{MgSO}_{4}, 6 \mathrm{MgCl}_{2}$, and 10 D-glucose, equilibrated with $95 \%$ $\mathrm{O}_{2}$ and $5 \% \mathrm{CO}_{2}$.

For quality control, subsets of slices, each from a given animal, were used in parallel for protein analysis and electrophysiological recordings (see Discussion).

Quantitative immunoblots. Hippocampal slices used for immunoblots were prepared as described above. They were homogenized in RIPA buffer $(150 \mathrm{~mm} \mathrm{NaCl}, 1 \%$ Triton X-100, 0.5\% deoxycholic acid, $0.1 \%$ SDS, and $50 \mathrm{~mm}$ Tris- $\mathrm{Cl}, \mathrm{pH} 8.0$ ) with a protease inhibitor mixture (Complete Mini EDTA-free protease inhibitor mixture; Roche). Proteins were separated by SDS-PAGE. Loading was performed in SDS-PAGE sample buffer containing $80 \mathrm{~mm}$ Tris- $\mathrm{HCl}, 2 \%$ SDS, $10 \%$ glycerol, $5.3 \%$ $\beta$-mercaptoethanol, and $2 \%$ bromophenol blue. After electrophoretic separation, proteins were electrophoretically transferred to nitrocellulose membranes (PerkinElmer) in transfer buffer containing $25 \mathrm{~mm}$ Tris, $192 \mathrm{~mm}$ glycine, and 10\% methanol, pH 8.3. Membranes were blocked in TBST/milk (20 mM Tris, $150 \mathrm{~mm} \mathrm{NaCl}, 0.1 \%$ Tween 20 , and $0.5 \%$ nonfat dry milk, $\mathrm{pH}$ 7.5) for $1 \mathrm{~h}$ at room temperature. Incubation with the respective antiserum diluted in TBST/milk was performed overnight in the refrigerator with agitation. Rabbit-anti-panKCC2 (1:1000; raised against amino acid residues $929-1045$ of rat KCC2; Ludwig et al., 2003) and rabbit-anti-NTD-KCC2 (1:2000; raised against amino acid residues 1-93 of rat KCC2; Blaesse et al., 2006) were used for KCC2 and rabbitanti-tubulin (1:20,000; Nordic BioSite, catalog no. PRB-435P) for the neuronal class III tubulin.

The secondary antibodies, donkey-anti-rabbit IgG horseradish peroxidase-conjugated (1:3000; GE Healthcare) and goat-anti-mouse IgG horseradish peroxidase-conjugated (1:3000; Dako), were applied for $2-4 \mathrm{~h}$ at room temperature in TBST/milk with agitation. The immunoreactivity was detected using an enhanced chemiluminescence kit (Pierce) and a LAS-3000 documentation system (Fujifilm).

Quantification of the chemiluminescence signals was performed by Advanced Image Data Analysis software (Raytest) or ImageJ (http://rsb.info.nih.gov/ij/). All measurements were within the linear range of the sensitivity of the camera. After quantification, the representative images included in the figures were optimized for brightness and contrast using Paint Shop Pro X (Corel).

In vitro assay of calpain cleavage. Rat brain homogenate was diluted to about $1-2 \mathrm{mg} / \mathrm{ml}$ of protein in a final volume of $500 \mu \mathrm{l}$ (as assessed by a DC protein assay kit; Bio-Rad). Rat calpain-2 (i.e., m-calpain; Calbiochem) was added at a concentration of $31.5 \mathrm{U} / \mathrm{ml}$ in calpain assay buffer (100 mм HEPES, $50 \mathrm{~mm} \mathrm{NaCl}$, 0.1\% Triton X-100, $20 \mathrm{~mm} \mathrm{CaCl}_{2}$, and 20 mm dithiothreitol). The cleavage reaction was stopped after 10, 20, or 30 min by adding $0.1 \mathrm{M}$ EDTA and protease inhibitors (Complete Mini EDTA-free protease inhibitor mixture; Roche). In some experiments, calpain-2 was preincubated with $100 \mu \mathrm{M}$ MDL-28170 for $5 \mathrm{~min}$.

Ionomycin assay of calpain activation. To directly raise the intracellular $\mathrm{Ca}^{2+}$ concentration $\left(\left[\mathrm{Ca}^{2+}\right]_{\mathrm{i}}\right)$, coronal rat brain slices were treated with $50 \mu \mathrm{M}$ ionomycin (Ascent Scientific), a $\mathrm{Ca}^{2+}$ ionophore, at $32^{\circ} \mathrm{C}$ for $4 \mathrm{~h}$. Slices treated with ionomycin and $30 \mu \mathrm{M}$ MDL-28170 were preincubated with MDL-28170 for $30 \mathrm{~min}$.

Analysis of surface expression. A recently developed protease approach (Khirug et al., 2010; Ahmad et al., 2011) was used to analyze the surface expression of KCC2. Briefly, transverse hippocampal slices were treated with cod trypsin (Zymetech), a protease that retains its activity at low temperatures while trafficking of membrane proteins is blocked. Slices were incubated on ice for $60 \mathrm{~min}$ in the presence of cod trypsin $(2 \mathrm{U} / \mathrm{ml})$. The cleavage reaction was stopped by adding the trypsin inhibitor phenylmethylsulfonyl fluoride (100 $\mu \mathrm{M} ; 5 \mathrm{~min}$ on ice). After homogenization, $30 \mu \mathrm{g}$ of protein was separated on a $6 \%$ acrylamide gel and the immunoblot analysis was performed as described above.

Electrophysiological recordings. Cell-attached and whole-cell patchclamp recordings were done at $32^{\circ} \mathrm{C}$ from visually identified CA1 pyramidal neurons using an EPC 10 amplifier and Pulse software (HEKA). Patch pipettes were fabricated from borosilicate glass (Harvard Apparatus), and their resistance ranged from 4.5 to $6.5 \mathrm{M} \Omega$. The pipette solution consisted of (in mM): $30 \mathrm{~N}$-methyl-D-glucamine-HCl, $95 \mathrm{~K}$-gluconate, 1 EGTA, 5 HEPES, 10 D-glucose, 2 Mg-ATP, 20 sucrose, 0.1 Alexa Fluor 488, $2 \mathrm{NaOH}$, and $5.4 \mathrm{KOH}, \mathrm{pH}$ 7.3. For recordings, slices were positioned in a submerged-type recording chamber and continuously perfused at a rate of $3.5 \mathrm{ml} / \mathrm{min}$ with extracellular solution containing (in mм): $124 \mathrm{NaCl}, 3.5 \mathrm{KCl}, 2 \mathrm{CaCl}_{2}, 25 \mathrm{NaHCO}_{3}, 1.1 \mathrm{NaH}_{2} \mathrm{PO}_{4}, 2 \mathrm{MgSO}_{4}$, and 10 D-glucose, equilibrated with $95 \% \mathrm{O}_{2}$ and $5 \% \mathrm{CO}_{2}, \mathrm{pH}$ 7.4. Membrane potential values were corrected for calculated liquid junction potentials (Barry, 1994). Interictal-like activity was induced by omitting $\mathrm{Mg}^{2+}$ from the extracellular solution after recovery and during the recordings (Anderson et al., 1986; Mody et al., 1987; Rivera et al., 2004). Some of the slices failed to generate interictal-like activity under $0-\mathrm{Mg}^{2+}$ conditions, therefore activity was verified before whole-cell recordings and immunoblotting using the current-clamp $I=0$ configuration in cell-attached mode in the presence of $10 \mu \mathrm{m}$ bumetanide and $1 \mu \mathrm{M}$ CGP 55845. In the majority of cases, $\mathrm{KCC}^{-}$-mediated $\mathrm{Cl}^{-}$extrusion (see below) was measured in one cell per slice under $0-\mathrm{Mg}^{2+}$ conditions, and when two cells were recorded the network activity was assessed in the first cell only. Spike frequency was analyzed using WinEDR software (Dr. John Dempster, University of Strathclyde, Glasgow, UK). In experiments with the calpain inhibitor MDL-28170, a 30 min preincubation with 30 $\mu \mathrm{M}$ MDL-28170 was done before $\mathrm{Mg}^{2+}$ was omitted. Exposure to $30 \mu \mathrm{M}$ MDL-28170 or $100 \mu \mathrm{M}$ cycloheximide was maintained throughout the experiments. Somatic whole-cell, voltage-clamp recordings were done in the presence of $0.5 \mu \mathrm{M}$ TTX (Ascent Scientific), $10 \mu \mathrm{M}$ CNQX (Ascent Scientific), $10 \mu \mathrm{M}$ bumetanide, and $1 \mu \mathrm{M}$ CGP 55845. After rupturing the seal, each neuron was allowed to equilibrate with the pipette solution for at least 5-10 min. Cells with stable access resistance between 10 and 20 $\mathrm{M} \Omega$, and resting membrane potential below $-55 \mathrm{mV}$ were accepted for analysis. The efficacy of KCC2-mediated $\mathrm{Cl}^{-}$extrusion was quantified on the basis of $\Delta E_{\mathrm{GABA}}$, which was measured as the difference between the reversal potential of $\mathrm{GABA}_{\mathrm{A}}$-mediated currents $\left(E_{\mathrm{GABA}}\right)$ at the soma and at $50 \mu \mathrm{m}$ away along the apical dendrite (Khirug et al., 2010). Membrane potential was held at $-50 \mathrm{mV}$ to reduce the driving force for outward leak $\mathrm{Cl}^{-}$conductance and to minimize its contribution to the measured $\mathrm{Cl}^{-}$extrusion. Under the present conditions, the $\mathrm{Cl}^{-}$load of $30 \mathrm{~mm}$ would generate an $E_{\mathrm{GABA}}$ of $-39.5 \mathrm{mV}$ as calculated from the Goldman-Hodgkin-Katz voltage equation (Farrant and Kaila, 2007). Indeed, control measurements of somatic $E_{\mathrm{GABA}}$ yielded a value of $-40.7 \pm 0.41 \mathrm{mV}(n=26)$, demonstrating that the somatic $\left[\mathrm{Cl}^{-}\right]_{\mathrm{i}}$ of CA1 pyramidal neurons was clamped at the $\left[\mathrm{Cl}^{-}\right]$of the pipette. Thus, under these conditions, a negative deviation of the dendritic $E_{\mathrm{GABA}}$ from the somatic value (i.e., $\Delta E_{\mathrm{GABA}}$ ) is a quantitative measure of the efficacy of $\mathrm{Cl}^{-}$extrusion (Jarolimek et al., 1999; Khirug et al., 2005). Somatic and dendritic $E_{\mathrm{GABA}}$ values were determined from the current-voltage rela- 

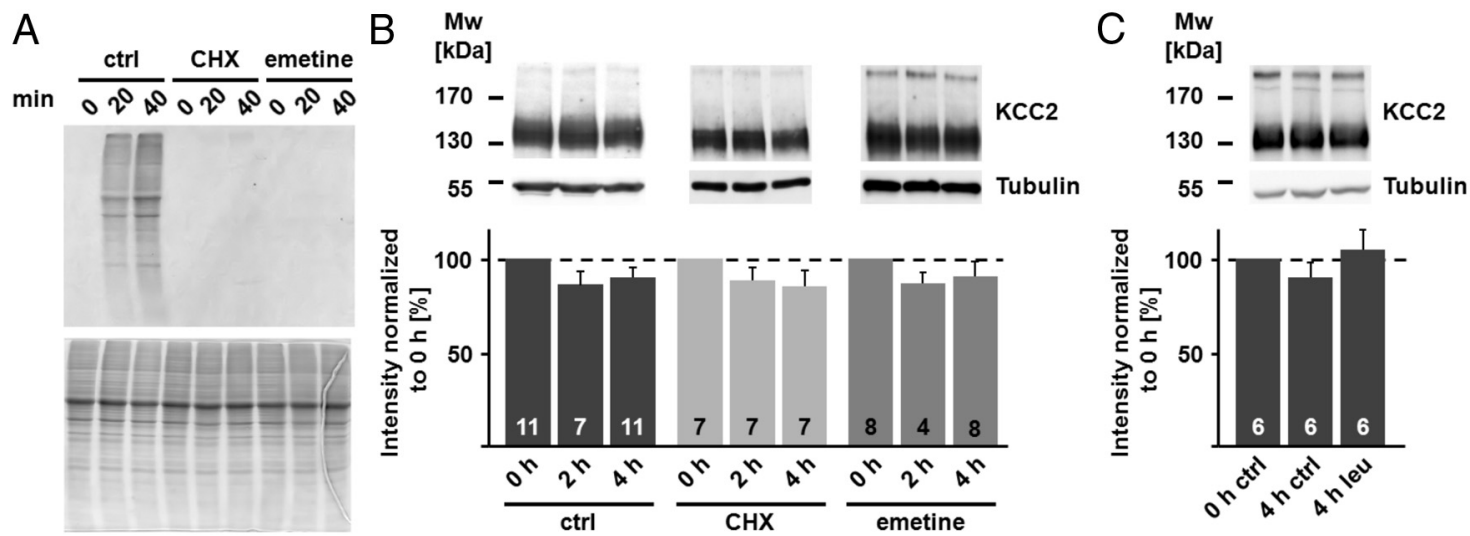

Figure 1. Blocking protein synthesis does not affect KCC2 protein level. $\boldsymbol{A}$, Application of $100 \mu \mathrm{m}$ cycloheximide (CHX) or $100 \mu \mathrm{m}$ emetine inhibited the incorporation of [ ${ }^{35} \mathrm{~S}$ ]methionine in hippocampal slices (autoradiogram, top). SDS-PAGE demonstrated that similar amounts of protein were loaded (Coomassie-stained gel, bottom). $\boldsymbol{B}$, Immunoblots with homogenates from hippocampal slices incubated in CHX and emetine. The tubulin signal ( $55 \mathrm{kDa}$ ) confirmed that similar protein amounts were loaded. The KCC2 signal ( $\sim 140 \mathrm{kDa}$ ) did not differ significantly from the corresponding controls (ctrl) after $4 \mathrm{~h}$ under arrested protein synthesis (ctrl: $90.3 \pm 5.2 \%$; CHX: $85.3 \pm 8.4 \%$; emetine: $90.6 \pm 8.0 \%$; $p=0.824$ ). Statistical significance was assessed by Kruskal-Wallis one-way ANOVA on Ranks with Mann-Whitney's post hoc test. C, Application of $50 \mu \mathrm{m}$ leupeptin (leu) for $4 \mathrm{~h}$ did not induce significant changes in the KCC2 protein level in hippocampal slices (105.1 $\pm 10.6 \%$ ). Statistical significance was assessed by one-way ANOVA. The values for $n$ are given in the bar diagram. Error bars denote SEM.

tions, obtained by sequentially clamping the membrane potential at different holding potentials with a $5 \mathrm{mV}$ increment and a $10 \mathrm{~s}$ step interval. Caged GABA was photolyzed $50 \mathrm{~ms}$ after the start of each voltage step to evoke local GABA A receptor-mediated currents (Khirug et al., 2005). To this end, 1 mM DPNI-caged GABA dissolved in extracellular solution was delivered at a flow rate of $1-2 \mu \mathrm{l} / \mathrm{min}$ via an UltraMicroPump II (WPI) equipped with a syringe and a $100 \mu \mathrm{m}$ inner tip diameter quartz needle (WPI) and locally photolyzed using the $375 \mathrm{~nm}$ output of a continuous emission diode laser (Excelsior 375; Spectra Physics). An electronic shutter (AA Opto-Electronic) was used to set the duration of the laser pulse at $10 \mathrm{~ms}$ and a LUMPlanFI $60 \times$ water-immersion objective (Olympus) to focus the $\sim 10 \mu \mathrm{m}$ uncaging spot either at the soma or at $50 \mu \mathrm{m}$ away on the apical dendrite. To accurately measure the distance from the soma, Alexa Fluor 488 (Life Technologies) was dialyzed via the patch pipette, and dendrites were traced using a Radiance 2100 confocal microscope (Bio-Rad).

Statistical analysis. One-way ANOVA was used to compare groups when data were normally distributed. Kruskal-Wallis one-way ANOVA on ranks with Mann-Whitney's post hoc test was used if distributions were not normal. Statistical analysis was performed using Statistica (StatSoft) and WinStat (R. Fitch Software).

\section{Results}

Total block of protein synthesis does not affect KCC2 protein level or function in hippocampal slices for several hours

Under steady-state conditions, the rate of protein synthesis equals the rate of degradation. Hence, exposure of hippocampal slices to protein synthesis inhibitors will prevent the synthesis of new KCC2 protein molecules, after which the protein degradation rate is seen as decay in the KCC2 protein level. We first tested the efficacy of the protein synthesis inhibitors cycloheximide and emetine, both at $100 \mu \mathrm{M}$. As shown in Figure $1 A$, both drugs completely blocked the incorporation of ${ }^{35} \mathrm{~S}$-methionine, demonstrating fast and efficient block of protein synthesis. Surprisingly (cf. Rivera et al., 2004), the total amount of KCC2 protein did not change within $4 \mathrm{~h}$, neither under control conditions nor in the presence of cycloheximide or emetine (Fig. $1 B$; protein level after $4 \mathrm{~h}$ for control, cycloheximide, and emetine: $90.3 \pm$ $5.2 \%, 85.3 \pm 8.4 \%$, and $90.6 \pm 8.0 \%$ with $n=11, n=7$, and $n=$ 8 , respectively; $p=0.824$ ). Despite the consistent results obtained with the two different protein synthesis inhibitors, it should be noted that cycloheximide can block not only synthesis but also degradation of certain proteins (Cui et al., 2002). Therefore, we used another approach to study the turnover of KCC2. Membrane proteins are mainly degraded via the lysosomal pathway (Piper and Luzio, 2007), and leupeptin efficiently blocks lysosomal degradation without affecting protein synthesis (Seglen et al., 1979). In case of a high turnover rate of the total KCC2 protein pool, not only a decrease in KCC2 protein level under arrested protein synthesis is a likely scenario, but an increase in KCC2 after a blockage of protein degradation would also be expected. In line with the results obtained with the protein synthesis inhibitors, leupeptin $(50 \mu \mathrm{M})$ did not induce significant changes in KCC2 protein levels within $4 \mathrm{~h}$ (Fig. 1C; KCC2 protein level after incubation in the presence of leupeptin for $4 \mathrm{~h}$ : $105.1 \pm 10.6 \%$ when compared to the 0 h control; $n=6$ ).

To study the effect of blocking protein synthesis on the functional KCC2 pool, we used an electrophysiological assay to measure $\mathrm{KCC} 2-$ mediated $\mathrm{Cl}^{-}$extrusion (Khirug et al., 2005; Li et al., 2007). Because of the similar results obtained with the two protein synthesis inhibitors in the biochemical assays (Fig. 1), we used cycloheximide only in the functional assay. Imposing a defined somatic $\mathrm{Cl}^{-}$load via the patch pipette enables assessment of the efficacy of $\mathrm{Cl}^{-}$extrusion. As shown previously (Khirug et al., 2005, 2008, 2010; Blaesse et al., 2006; Li et al., 2007; Gauvain et al., 2011), functional expression of KCC2 results in a somatodendritic gradient of $\left[\mathrm{Cl}^{-}\right]_{\mathrm{i}}$, which can be measured as a gradient in $E_{\mathrm{GABA}}$ between the somatic and dendritic compartments $\left(\Delta E_{\mathrm{GABA}}\right)$. Notably, control levels of $\Delta E_{\mathrm{GABA}}$ remained unchanged for the experimental duration of $0-4 \mathrm{~h}(0-2 \mathrm{~h}:-6.05 \pm$ $0.31 \mathrm{mV} / 50 \mu \mathrm{m} ; n=12$ cells; $3-4 \mathrm{~h}:-6.28 \pm 0.28 \mathrm{mV} / 50 \mu \mathrm{m}$; $n=14$ cells). While the application of the KCC2 inhibitor furosemide $(1.5 \mathrm{mM}$, in the continuous presence of $10 \mu \mathrm{M}$ bumetanide; see Materials and Methods; Payne et al., 2003; Blaesse et al., $2009)$ induced a highly significant reduction in $\Delta E_{\mathrm{GABA}}(0-4 \mathrm{~h}$ : $-3.03 \pm 0.30 \mathrm{mV} / 50 \mu \mathrm{m} ; n=8$ cells; $p<0.001$ ), cycloheximide had no effect on $\Delta E_{\mathrm{GABA}}$ when measured during the fourth hour of incubation ( $-5.52 \pm 0.36 \mathrm{mV} / 50 \mu \mathrm{m} ; n=8$ cells; Fig. 2$)$.

KCC2 is a substrate of the calcium-activated protease calpain The absence of effect on the KCC2 protein level and function by arrest of mRNA translation under control conditions indicates that a fast decrease in $\mathrm{KCC} 2$, as seen under pathophysiological 

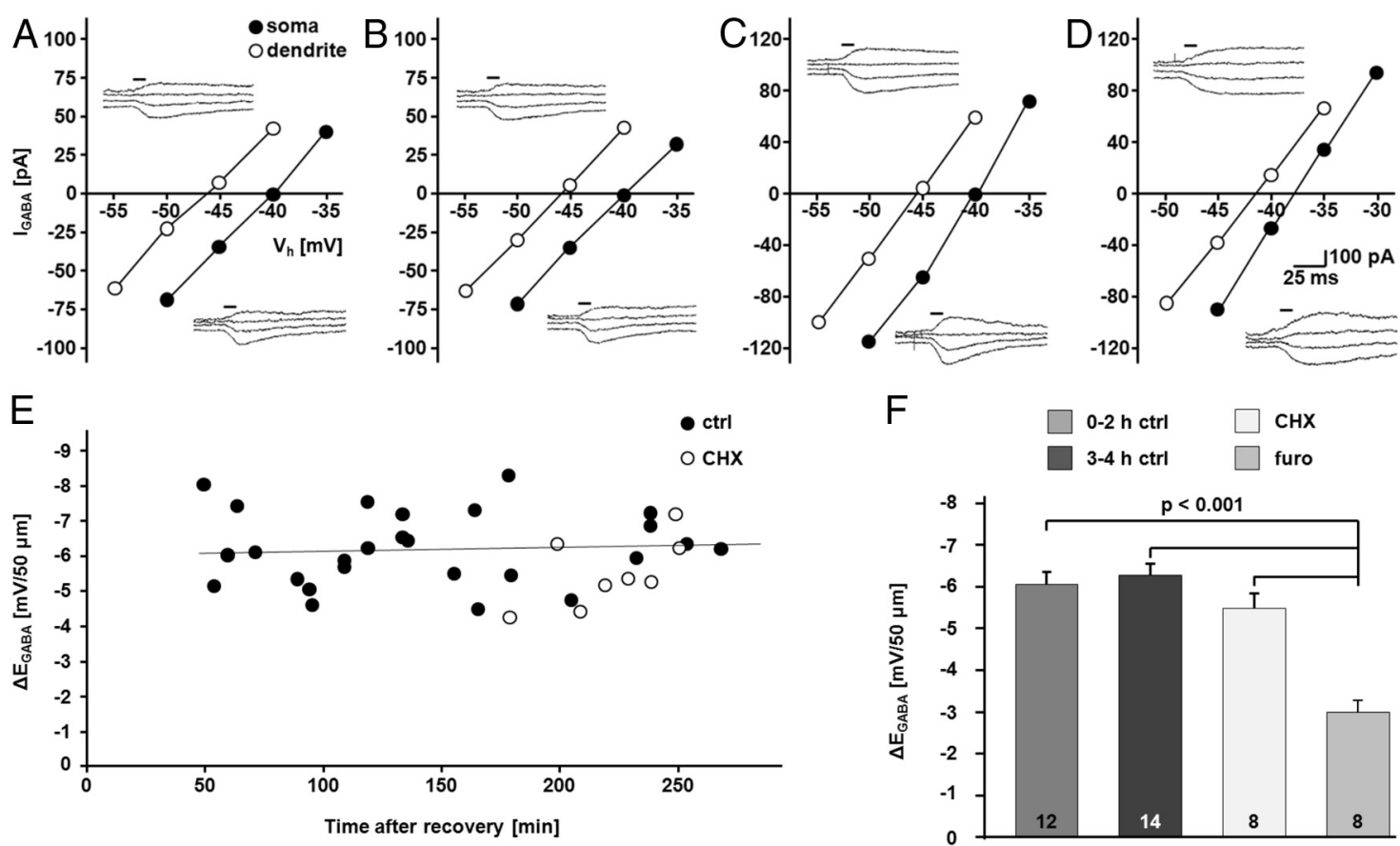

Figure 2. Blocking protein synthesis does not affect $K C C 2$ function. $\boldsymbol{A}-\boldsymbol{F}$, Whole-cell, patch-clamp recordings of uncaging-induced $G A B A_{A}$-mediated currents $\left(I_{G A B A}\right)$ and $E_{G A B A}$ in $C A 1$ pyramidal neurons with an artificially imposed somatic $\mathrm{Cl}^{-}$load showed that $\mathrm{CA} 1$ pyramidal neurons were able to generate a furosemide (furo)-sensitive somatodendritic $\Delta E_{\mathrm{GABA}}$ that was stable for at least 4 h under control conditions. $C H X(100 \mu \mathrm{M})$ did not induce a change $\Delta E_{G A B A} \cdot A-D$, Sample $E_{G A B A}$ recordings at the soma and at a distance of $50 \mu$ mat the apical dendrite. $I-V$ curves are based on $I_{G A B A}$ at different holding potentials $\left(V_{\mathrm{h}}\right) \cdot \boldsymbol{A}, 0-2 \mathrm{~h} \mathrm{ctrl} ; \boldsymbol{B}, 3-4 \mathrm{~h}$ ctrl; $\boldsymbol{C}, \mathrm{CHX} ; \boldsymbol{D}$, furo. Uncaging flash indicated by horizontal bars. $\boldsymbol{E}$, Scatter plot of $\Delta E_{\mathrm{GABA}}$ over time in control and CHX-treated CA1 neurons. The line represents a linear fit for the control cells. $F$, Quantification of $\Delta E_{\mathrm{GABA}}$ revealed stable gradients over time under control conditions $(0-2 \mathrm{~h}:-6.05 \pm 0.31 \mathrm{mV} / 50 \mu \mathrm{m} ; 3-4 \mathrm{~h}:-6.28 \pm 0.28 \mathrm{mV} / 50 \mu \mathrm{m}) . \Delta E_{\mathrm{GABA}}$ Was not affected by CHX $(-5.52 \pm 0.36 \mathrm{mV} / 50 \mu \mathrm{m})$, but was sensitive to furosemide $(0-4 \mathrm{~h}:-3.03 \pm 0.30 \mathrm{mV} / 50 \mu \mathrm{m} ; p<0.001)$. The experiments were done in the continuous presence of $10 \mu \mathrm{m}$ bumetanide. Statistical significance was assessed by one-way ANOVA with Scheffe's post hoc test. The values for $n$ are given in the bar diagram. Error bars denote SEM.

conditions, cannot be mediated by changes in KCC2 transcription and translation only.

It has been speculated that the two PEST domains that have been identified within the KCC2 sequence might be involved in the regulation of KCC2 by proteases such as calpain (Mercado et al., 2006). Strikingly, an almost complete loss of KCC2 immunoreactivity was seen when rat brain homogenate was exposed to $31.5 \mathrm{U} / \mathrm{ml}$ recombinant rat calpain-2 for up to 30 min (Fig. $3 A$ ), and this effect was blocked by the calpain inhibitor MDL-28170. The peptide used for the generation of the anti-KCC2 antibody covers the region encoding the PEST domains. Therefore, the decrease in the intensity of the immunoreactive signal at $\sim 140 \mathrm{kDa}$ can be explained by complete degradation of the protein or by discrete calpain-mediated cleavage in the region that forms the epitope. An antibody directed against the N-terminal domain of KCC2 (anti-NTDKCC2; Blaesse et al., 2006) detected a fragment with a molecular weight of $\sim 100 \mathrm{kDa}$ (Fig. $3 B$ ), indicating that a large part of the cytoplasmic C-terminal domain (CTD) is cleaved off. Based on the known importance of the CTD for KCC2 function (Mercado et al., 2006; Acton et al., 2012), it is likely that the truncated protein is nonfunctional as a $\mathrm{K}-\mathrm{Cl}$ cotransporter.

To test whether KCC2 is a calpain substrate in neurons, we incubated brain slices in the presence of ionomycin. Ionomycin triggers an increase in $\left[\mathrm{Ca}^{2+}\right]_{\mathrm{i}}$ and has been often used to activate calpain both in vitro (e.g., Gil-Parrado et al., 2002) and in vivo (Stockholm et al., 2005). Incubation of brain slices in the presence of $50 \mu \mathrm{M}$ ionomycin resulted in a decrease in the KCC2 protein level after $4 \mathrm{~h}$ (Fig. 3C,D;39.6 $\pm 2.6 \% ; n=5 ; p<0.05$ ), an effect that was blocked by co-application of MDL-28170 $(86.6 \pm 8.3 \% ; n=4)$.
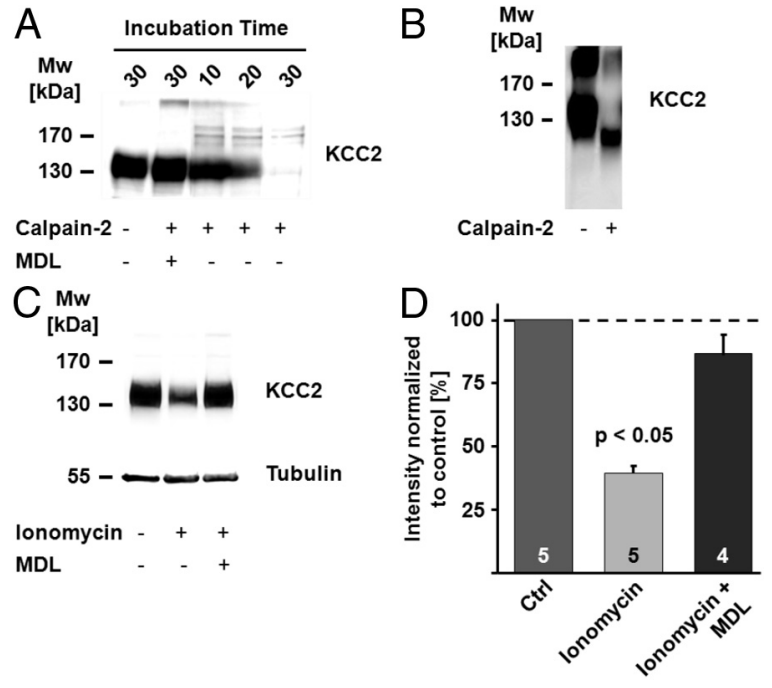

Figure 3. $K C C 2$ is a calpain substrate. $A$, The $K C C 2$ signal in an immunoblot decreased when rat brain homogenate was exposed to $31.5 \mathrm{U} / \mathrm{ml}$ recombinant rat calpain-2. An almost complete loss of the KCC2 immunosignal was observed after $30 \mathrm{~min}$. The decrease in the KCC 2 signal was blocked by the calpain inhibitor MDL-28170 (MDL). B, An immunoblot with an antibody directed against an N-terminal epitope of KCC2 (anti-NTD-KCC2) showed a truncated $\mathrm{N}$-terminal fragment of $\mathrm{KCC} 2$ with a molecular weight $(\mathrm{Mw})$ of $\sim 100 \mathrm{kDa}$. C, D, lonomycin triggers a decrease in $K C C 2$ protein level. $C$, Incubation of brain slices in the presence of the $\mathrm{Ca}^{2+}$ ionophore ionomycin ( $50 \mu \mathrm{m} ; 4 \mathrm{~h}$ ) resulted in a clear reduction in KCC2 protein level, an effect that was blocked when ionomycin was applied together with MDL-28170. D, The mean values of the quantified immunoblot signals showed a significant decrease in $\mathrm{KCC} 2$ after ionomycin treatment $(39.6 \pm 2.6 \% ; p<0.05)$. The mean value of the ionomycin plus MDL-28170 samples did not differ from control (Ctrl; $86.6 \pm 8.3 \% ; p=0.477)$. Statistical significance was assessed by One-way ANOVA with Scheffe's post hoc test. The values for $n$ are given in the bar diagram. Error bars denote SEM. 


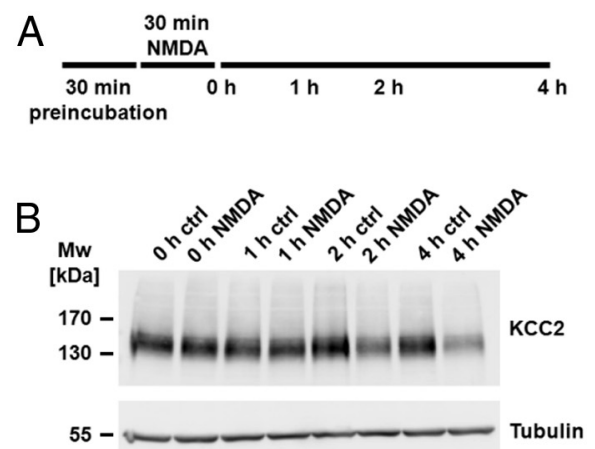

$\mathrm{D}$
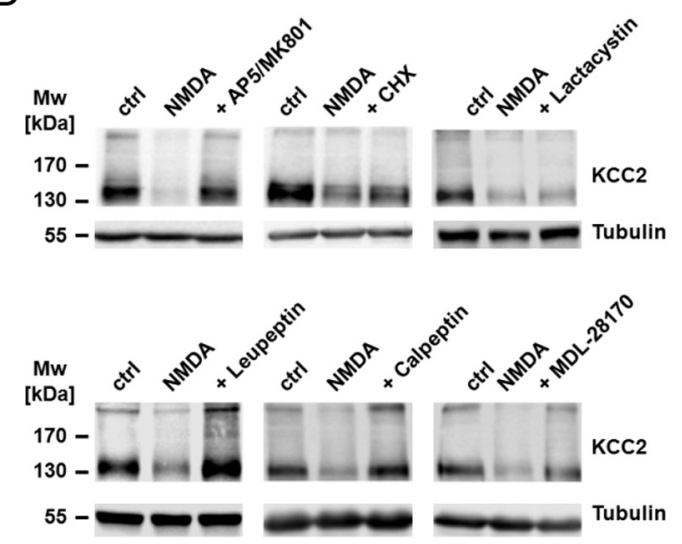

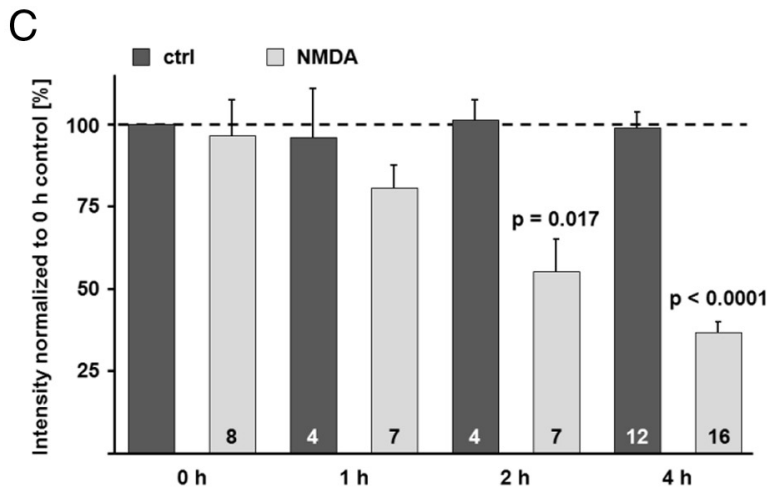

E

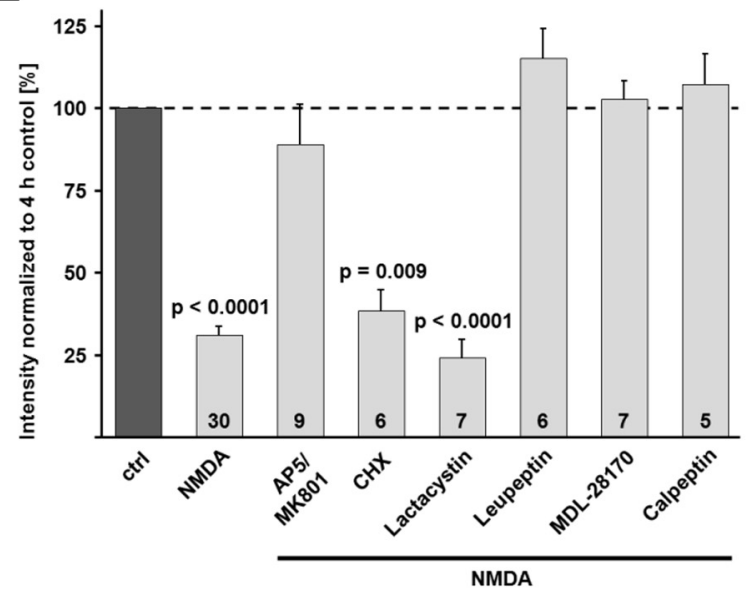

Figure 4. NMDA-induced excitotoxicity leads to calpain-mediated KCC2 degradation. $A$, Scheme of the experimental design. Coronal brain slices were preincubated in the presence of different combinations of inhibitors (see Materials and Methods for details). At the end of the preincubation, NMDA (100 $\mu \mathrm{m}$ ) was added for $30 \mathrm{~min}$. The end of the NMDA incubation was defined as time point $0 \mathrm{~h} . \boldsymbol{B}$, The NMDA incubation induced a rapid decrease in the KCC2 protein level. Tubulin was used as a loading control. $\boldsymbol{C}$, The mean values of the quantified immunoblot signals showed a significant decrease in the KCC2 signal after the NMDA incubation ( $80.6 \pm 7.0 \%$ of the $K C C 2$ protein level in the $0 \mathrm{~h}$ control after $1 \mathrm{~h} ; 55.1 \pm 9.8 \%$ after $2 \mathrm{~h} ; 36.6 \pm 3.4 \%$ after $4 \mathrm{~h}$ ), while the signal remained stable under control conditions ( $98.7 \pm 5.0 \%$ after $4 \mathrm{~h}$ ). $\boldsymbol{D}, \boldsymbol{E}$, Application of NMDA in the presence of the NMDAR antagonists AP5 and MK-801 (100 and $10 \mu \mathrm{M})$ blocked the degradation of KCC2 $(89.0 \pm 12.1 \%)$. The protein synthesis inhibitor cycloheximide had no effect on the NMDA-induced degradation of KCC2 (38.5 $\pm 6.3 \%)$. The proteasome inhibitor lactacystin $(1 \mu \mathrm{M})$ did not prevent the downregulation of KCC2 (24.3 $\pm 5.7 \%)$. The inhibitor of lysosomal degradation, leupeptin $(50 \mu \mathrm{m})$, blocked the decrease in KCC2 protein (115.3 $\pm 8.8 \%)$. The two calpain inhibitors MDL-28170 (MDL) $(30 \mu \mathrm{M})$ and calpeptin $(30 \mu \mathrm{M})$ both blocked the NMDA-induced degradation of KCC2 (102.9 $\pm 5.7 \%$ and $107.3 \pm 9.2 \%)$. Statistical significance was assessed by Kruskal-Wallis one-way ANOVA on Ranks with Mann-Whitney's post hoc test. The values for $n$ are given in the bar diagram. Error bars denote SEM.

Incubation of hippocampal slices in the presence of the glutamate receptor agonist NMDA for 30 min leads to a fast activation of calpain as seen by the degradation of the canonical calpain substrate spectrin (Siman and Noszek, 1988; Zhou and Baudry, 2006). We preincubated coronal brain slices, including the hippocampus, for $30 \mathrm{~min}$ in the presence of $0.5 \mu \mathrm{M}$ TTX to block action potentials, $50 \mu \mathrm{M}$ picrotoxin to block $\mathrm{GABA}_{\mathrm{A}}$ receptors, and $1 \mu \mathrm{M}$ CGP 55845 to block $\mathrm{GABA}_{\mathrm{B}}$ receptors. At the end of the preincubation, NMDA $(100 \mu \mathrm{M})$ was added. The end of the $30 \mathrm{~min}$ incubation of hippocampal slices in NMDA was defined as time point $0 \mathrm{~h}$ (Fig. $4 A$ ). A decrease in the KCC2 protein level was evident already $1 \mathrm{~h}$ after the end of the NMDA incubation $(80.6 \pm 7.0 \%$ of the KCC2 protein level in the $0 \mathrm{~h}$ control), became significant after $2 \mathrm{~h}(55.1 \pm$ $9.8 \% ; p=0.017)$, and was even bigger after $4 \mathrm{~h}(36.6 \pm 3.4 \%$; $p<0.0001$; Fig. $4 B, C$ ). Interestingly and in contrast to previous results (Rivera et al., 2004), the KCC2 protein level in hippocampal slices remained stable under control conditions within the experimental time window of up to $5 \mathrm{~h}$ after recovery $(98.7 \pm 5.0 \%)$. In a further set of experiments, the downstream mechanisms of NMDA action on protein degradation were investigated in more detail (Fig. $4 D, E$ ). Slices treated for
30 min with NMDA and kept for additional $4 \mathrm{~h}$ confirmed the NMDA-induced degradation of KCC2 seen in the previous experiments $(31.0 \pm 3.0 \%$ of the KCC 2 protein level in the $4 \mathrm{~h}$ control; $p<0.0001)$. Application of the NMDA receptor (NMDAR) blockers AP5 and MK-801 (100 and $10 \mu \mathrm{M}$, respectively) blocked the degradation of KCC2 (89.0 $\pm 12.1 \%)$, an effect consistent with previous results that demonstrated that inhibition of the NMDARs prevents the activation of calpain (Siman et al., 1989; Zhou and Baudry, 2006; Xu et al., 2007). Because it has been demonstrated that cycloheximide can block the degradation of certain proteins (Cui et al., 2002), we tested the effect of cycloheximide in the NMDA assay. Cycloheximide had no effect on the NMDA-induced degradation of KCC2 (38.5 $\pm 6.3 \% ; p=0.009$ when compared to control). While the proteasome inhibitor lactacystin $(1 \mu \mathrm{M})$ was not able to prevent the downregulation of KCC2 $(24.3 \pm 5.7 \%$; $p<0.0001$ when compared to control), the protease inhibitor leupeptin $(50 \mu \mathrm{M})$ blocked the decrease in KCC2 protein $(115.3 \pm 8.8 \%)$. Most interestingly, the two calpain inhibitors MDL-28170 and calpeptin (each $30 \mu \mathrm{M}$ ), both completely blocked the degradation of KCC2 in the NMDA excitotoxicity model $(102.9 \pm 5.7 \%$ and $107.3 \pm 9.2 \%)$. 

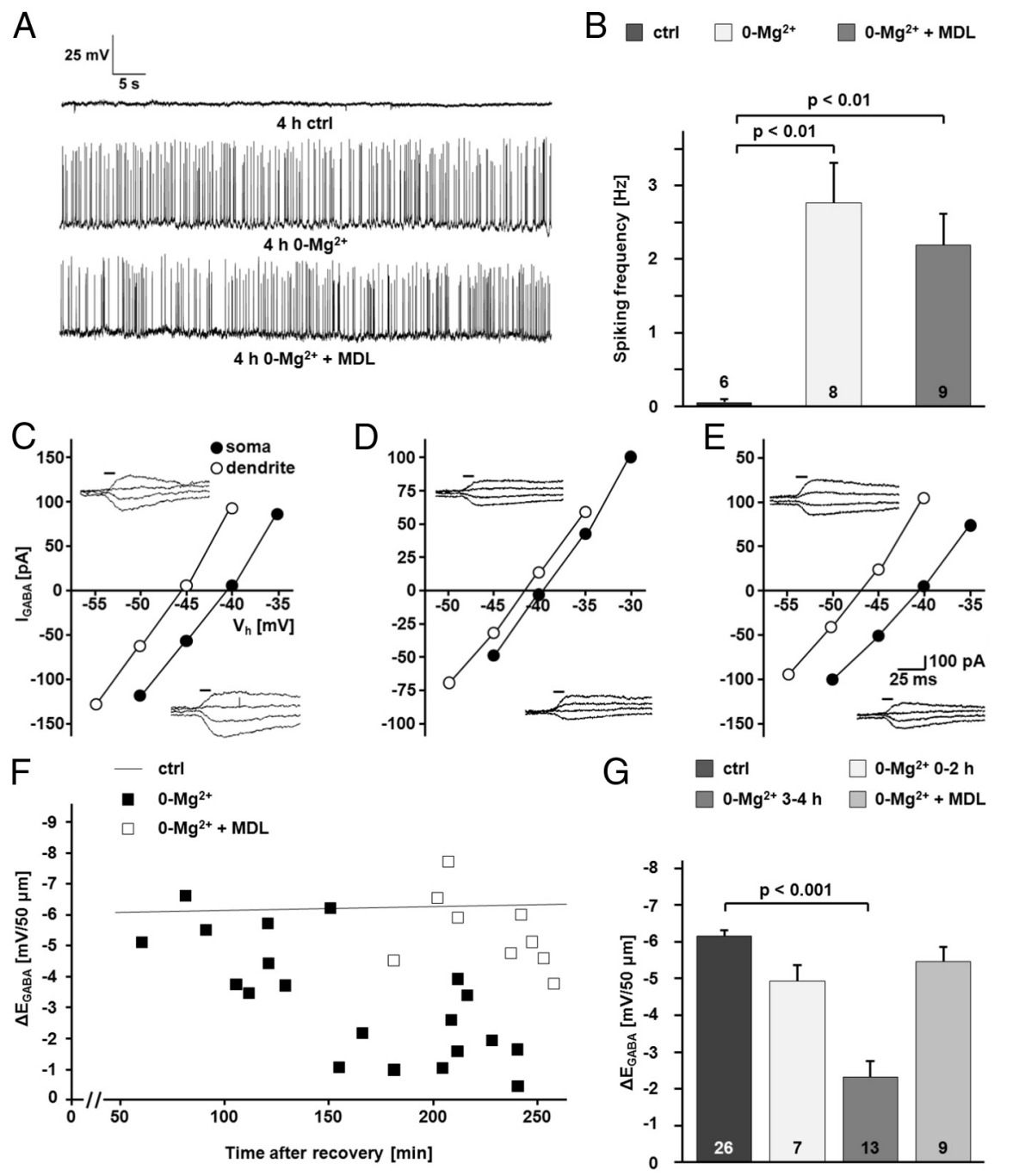

Figure 5. Interictal-like activity leads to a calpain-dependent functional inactivation of KCC2.A, Current-clamp recordings illustrating an increase in neuronal activity in CA1 pyramidal cells induced by the incubation of hippocampal slices in $\mathrm{Mg}^{2+}$-free physiological solution. The increase in activity was not blocked by the calpain inhibitor MDL-28170. B, Quantification of the current-clamp recordings. The increase in the spiking frequency in $\mathrm{Mg}^{2+}$-free physiological solution was significant $\left(2.77 \pm 0.57 \mathrm{Hzvs} 0.032 \pm 0.03 \mathrm{~Hz}\right.$ for $0-\mathrm{Mg}^{2+}$ and control (ctrl), respectively; $p<0.01$ ). The increase in frequency took also place when MDL-28170 (MDL) was present in the physiological solution ( $2.2 \pm 0.43 \mathrm{~Hz}$; not significantly different when compared to $0-\mathrm{Mg}^{2+}$ and $p<0.01$ when compared to control). C-E, Sample recordings of uncaging-induced $I_{G A B A}$ at the soma and at a distance of $50 \mu \mathrm{m}$ in the apical dendrite. $I-V$ curves are based on $I_{G A B A}$ at different holding potentials $\left(V_{h}\right)$ under control conditions $(\boldsymbol{C})$, in $\mathrm{Mg}^{2+}$-free physiological solution $(\boldsymbol{D})$, and in $\mathrm{Mg}^{2+}$-free physiological solution in the presence of MDL-28170 (E). $F$, Scatter plot of $\Delta E_{\mathrm{GABA}}$ over time in neurons kept in $\mathrm{Mg}^{2+}$-free physiological solution with or without MDL-28170. For comparison, the line representing the linear fit for the control cells shown in Figure 2 is included. G, Quantification of $\Delta E_{\text {GABA }}$ revealed a MDL-28170-sensitive decrease in the $\mathrm{Cl}^{-}$extrusion in neurons from slices incubated in $\mathrm{Mg}^{2+}$-free physiological solution (0-Mg $\left.{ }^{2+}:-2.33 \pm 1.62 \mathrm{mV} / 50 \mu \mathrm{m} ; \mathrm{MDL}-28170: 5.44 \pm 0.40 \mathrm{mV} / 50 \mu \mathrm{m} ; p<0.001\right)$. The pooled control data shown in Figure 2 are included for comparison. Statistical significance was assessed by one-way ANOVA with Scheffe's post hoc test. The values for $n$ are given in the bar diagram. Error bars denote SEM.

\section{Inhibition of calpain prevents the activity-induced} downregulation of KCC2 function

To investigate the possible role of calpain-mediated KCC2 degradation in activity-dependent downregulation of KCC2 function, we incubated transverse hippocampal slices in $\mathrm{Mg}^{2+}$-free physiological solution with or without the calpain inhibitor MDL-28170 (30 $\mu \mathrm{M})$. $\mathrm{Mg}^{2+}$ withdrawal induced interictal-like activity, which was quantified as spiking frequency recorded in cell-attached mode $(2.77 \pm 0.57 \mathrm{~Hz}$ vs $0.032 \pm 0.03 \mathrm{~Hz}$ with $n=8$ and $n=6$ cells for $0-\mathrm{Mg}^{2+}$ and control, respectively; $\left.p<0.01\right)$. MDL-28170 did not alter the frequency of interictal-like events $(2.2 \pm 0.43 \mathrm{~Hz}$; $n=9$ cells; not significantly different when compared to
$0-\mathrm{Mg}^{2+}$ and $p<0.01$ when compared to control; Fig. $5 A, B)$. Efficacy of $\mathrm{K}-\mathrm{Cl}$ cotransport, as measured by $\Delta E_{\mathrm{GABA}}$ from the CA1 pyramidal neurons in $0-\mathrm{Mg}^{2+}$. incubated slices, exhibited a timedependent decrease that was statistically highly significant after $3-4 \mathrm{~h}(-2.33 \pm$ $1.62 \mathrm{mV} / 50 \mu \mathrm{m} ; n=13$; $p<0.001$; Fig. $5 C-G)$. MDL-28170 prevented the activity-dependent downregulation of KCC2 function, and the $\Delta E_{\mathrm{GABA}}$ measured during the fourth hour was not different from control values $(5.44 \pm 0.40$ $\mathrm{mV} / 50 \mu \mathrm{m} ; n=9$; Fig. $5 C-G)$. In line with this, immunoblots demonstrated a decrease in the KCC2 protein level in the CA1 region from slices incubated for $4 \mathrm{~h}$ in $\mathrm{Mg}^{2+}$-free physiological solution (76.7 $\pm 6.0 \% ; n=13 ; p=0.038$; Fig. $6 A, B)$. The NMDAR antagonist AP5 (50 $\mu \mathrm{M} ; 114.4 \pm 9.4 \% ; n=8 ; p=0.001$ when compared to $0-\mathrm{Mg}^{2+}$ ), as well as the calpain inhibitor MDL-28170 (106.0 \pm $5.2 \% ; n=12 ; p=0.010$ when compared to $\left.0-\mathrm{Mg}^{2+}\right)$, prevented the downregulation of KCC2 (Fig. 6A, B). The decrease in the protein level of KCC2 was smaller compared to the downregulation seen in the NMDA model (Fig. 4). An explanation for this difference is that while NMDA exposure affects both synaptically connected and disconnected neurons in a slice preparation, it is not likely that all CA1 neurons in a slice are recruited into the interictal-like activity.

The decrease in the total protein level of KCC2 was paralleled by an activity-induced decrease in the surface expression of the transporter as shown by the cod trypsin assay (Fig. 6C,D). The surface/intracellular ratio was lower in the $0-\mathrm{Mg}^{2+}$ samples $(75.7 \pm 8.0 \% ; n=8 ; p=0.021$ when normalized and compared to control), an effect that was blocked by MDL-28170 (112.2 \pm $11.1 \% ; n=7 ; p=0.004$ when compared to $\left.0-\mathrm{Mg}^{2+}\right)$.

These findings demonstrate a critical role for calpain in regulating the neuronal $\mathrm{Cl}^{-}$extrusion capacity in response to NMDAR activation.

\section{Discussion}

The major finding of our study is that $\mathrm{KCC} 2$, a protein instrumental in the development and plasticity of $\mathrm{GABA}_{\mathrm{A}}$ receptormediated signaling (Blaesse et al., 2009) and in the maturation and function of dendritic spines and glutamatergic synapses (Li et al., 2007; Gauvain et al., 2011; Khalilov et al., 2011; Fiumelli et al., 2012), is a substrate of the calcium-activated protease calpain.

\section{Enhanced degradation of KCC2 leads to fast changes in GABAergic signaling}

The present data acquired using cycloheximide, emetine, and leupeptin all point to a rather low basal turnover of KCC2 (Fig. 

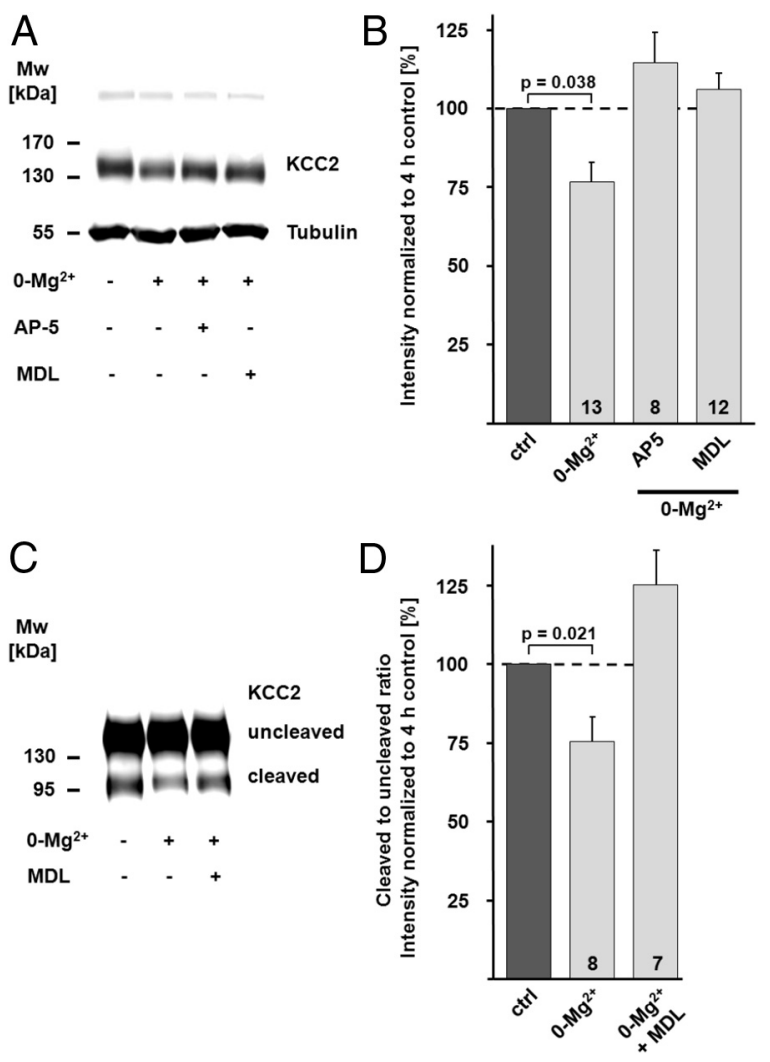

Figure 6. Interictal-like activity leads to a calpain-dependent decrease in $\mathrm{KCC} 2$ total protein level and surface expression. Interictal-like activity was induced by omitting $\mathrm{Mg}^{2+}$ from the extracellular solution. Slices were kept in $\mathrm{Mg}^{2+}$-free physiological solution until they were used for experiments. $\boldsymbol{A}, \boldsymbol{B}$, The KCC2 immunoreactivity was quantified and normalized in immunoblots with protein samples of $\mathrm{CA} 1$ regions isolated from pairs of control slices ( $\mathrm{Crl}$ ) and slices incubated in $\mathrm{Mg}^{2+}$-free physiological solution $\left(0-\mathrm{Mg}^{2+}\right)$. The $\mathrm{KCC} 2$ protein level in the $0-\mathrm{Mg}^{2+}$ group was significantly lower compared to control $(76.7 \pm 6.0 \%$ of control; $p=$ 0.038). The NMDAR antagonist AP5 ( $114.4 \pm 9.4 \%$ of control; $p=0.001$ when compared to $\left.0-\mathrm{Mg}^{2+}\right)$, as well as the calpain inhibitor MDL-28170 (MDL) (106.0 $\pm 5.2 \%$ of control; $p=$ 0.010 when compared to $0-\mathrm{Mg}^{2+}$ ), prevented the $0-\mathrm{Mg}^{2+}$-induced downregulation of $\mathrm{KCC} 2$. The tubulin signal verified that similar protein amounts were loaded. $C, D$, Protease treatment of hippocampal slices with cod trypsin demonstrated lower levels of surface KCC 2 in samples of CA1 regions isolated from $0-\mathrm{Mg}^{2+}$ slices. $\boldsymbol{D}$, The surface/intracellular (cleaved/uncleaved) ratio of $\mathrm{KCC} 2$ was normalized to the respective value in controls. The $\mathrm{KCC} 2$ surface/intracellular ratio was lower $(75.7 \pm 8.0 \% ; p=0.021)$ in $0-\mathrm{Mg}^{2+}$ slices. No significant change in the surface expression of KCC2 occurred when the calpain-inhibitor MDL-28170 was present (112.2 \pm $11.1 \%$ of control; $p=0.0037$ when compared to $0-\mathrm{Mg}^{2+}$ ). Statistical significance was assessed by Kruskal-Wallis one-way ANOVA on Ranks with Mann-Whitney's post hoc test. The values for $n$ are given in the bar diagram. Error bars denote SEM.

1). However, previous data obtained for leupeptin in neuronal cultures (Lee et al., 2010) and our previous analysis of the KCC2 surface pool in slices (Rivera et al., 2004) indicated a high turnover rate. The data presented here demonstrate that activation of calpain can lead to fast changes in KCC2 protein levels. While we previously saw a constant decrease $(0.2 \% / \mathrm{min})$ in the total KCC2 protein pool under control conditions (i.e., in standard physiological solution) in biochemical experiments (Rivera et al., 2004), the KCC2 protein level in the present study remained stable for at least $5 \mathrm{~h}$ after recovery under control conditions as well in the absence of protein synthesis. The difference between previous and present data is most likely attributable to nonoptimal slice preparation and maintenance conditions in the study by Rivera et al. (2004) that affected $\left[\mathrm{Ca}^{2+}\right]_{\mathrm{i}}$ levels and, consequently, calpain activity (Fig. $3 C, D$ ). In contrast to the above study, where some of the slices used for protein analysis were cut using a tissue chopper
(Thomas-Crusells et al., 2003; Rivera et al., 2004), all slices used in present work were cut using a vibratome. In addition, the standard physiological solution used for slicing and recovery/ storage used in the previous study was replaced by a sucrosebased cutting solution and a high $\mathrm{Mg}^{2+}$ recovery/storage solution. Most importantly, control for high slice quality in the present biochemical experiments was based on using a subset of slices (as in Fig. 4C), where slice batches from a given animal were used in parallel electrophysiological recordings with video microscopy (see Material and Methods).

The basal level of neuronal activity in the slice preparation does not seem to play a major role in the regulation of KCC2 turnover as indicated by the fact that the stability of KCC2 did not differ in the presence (control group in Fig. $4 B$ ) or absence of the $\mathrm{Na}^{+}$-channel blocker TTX (control group in Fig. $1 B$ ). Because both $\mu$ - and $\mathrm{m}$-calpain isoforms have a half-life of several days (Zhang et al., 1996) it is unlikely that the observed stability of KCC2 under arrested de novo translation is due to reduced calpain levels in the present experimental time window of $4 \mathrm{~h}$.

The low turnover rate of the total KCC2 protein is not consistent with several studies reporting fast functional changes in the efficacy of KCC2-mediated $\mathrm{Cl}^{-}$extrusion caused by changes in gene expression (for original references, Blaesse et al., 2009). The present data clearly show that an enhanced degradation rate of KCC2 is required to rapidly reduce KCC2 protein levels. The calpain-mediated cleavage of KCC2 presented here might be one of the major mechanisms responsible for an enhanced degradation of KCC2, while changes at the transcriptional level (Rivera et al., 2002; Huberfeld et al., 2007) are involved in long-term effects. It will be interesting to further investigate whether changes in the phosphorylation state of KCC2, which are also known to trigger an enhanced degradation, are involved in the regulation of calpain-mediated KCC2 cleavage. It has been demonstrated that an increase in lysosomal degradation of KCC2 takes place after the activation of muscarinergic acetylcholine receptors (mAChRs) in HEK cells and cultured hippocampal neurons (Lee et al., 2010). Phosphorylation of Tyr ${ }^{903 / 1087}$ of the KCC2 protein seems to be the main trigger for lysosomal degradation, and this phosphorylation takes also place when seizures are induced in adult mice by the injection of the mAChR agonist pilocarpine, paralleled by a fast decrease in KCC2 protein level (Lee et al., 2010). While this finding indicates that changes in the degradation rate of KCC2 do occur in vivo, the rates of synthesis and degradation of KCC2 under various conditions in vivo need to be addressed in future work. In contrast to phosphorylation of Tyr ${ }^{903 / 1087}$ in the pilocarpine model, glutamatergic NMDAR-mediated activity leading to EDTA-sensitive downregulation of KCC2 has been shown to coincide with protein phosphatase 1-dependent dephosphorylation of $\operatorname{Ser}^{940}$ (Lee et al., 2011).

\section{Calpain as a modulator of synaptic signaling}

PEST domains can serve to target proteins for calpain-mediated degradation but are not, however, a necessary feature of calpain substrates (Rechsteiner and Rogers, 1996; Wang et al., 2003). A recent study has shown that the vesicular GABA transporter (VIAAT) is downregulated by calpain in a PEST domaindependent manner (Gomes et al., 2011). Intriguingly, KCC2 contains two predicted PEST domains (Mercado et al., 2006). Future work should address the role of the KCC2 PEST domains, which are present only in the neuron-specific KCC2 but not in other KCC isoforms.

The calpain sensitivity of KCC2, VIAAT, and GABA synthesizing enzyme glutamic acid decarboxylase (Wei et al., 2006; Sha 
et al., 2008; Buddhala et al., 2012), as well as of the glycine transporters GlyT1 and GlyT2 (Baliova et al., 2004; Baliova and Jursky, 2005), suggests a more general calpain-mediated regulation of GABAergic and glycinergic neurotransmission. This idea gains further support from the finding that gephyrin, a key protein for clustering of GABA receptors (Kneussel and Betz, 2000) that colocalizes with KCC2 (Hübner et al., 2001), is also a calpain substrate (Tyagarajan et al., 2011). For the NMDAR 2 subunit, it has been shown that calpain-mediated cleavage is regulated by the interaction of the receptor and the postsynaptic density-95 protein, thereby endowing the calpain system with a high level of versatility (Dong et al., 2004).

In addition to activity-induced elevation in intracellular $\mathrm{Ca}^{2+}$, calpain is also activated by BDNF signaling (Zadran et al., 2010a). Seizure-induced upregulation of BDNF/TrkB signaling (Binder et al., 2001; Rivera et al., 2002) and activity-dependent endogenous release as well as exogenous application of BDNF (Rivera et al., 2002, 2004; Wake et al., 2007), all have been shown to downregulate KCC2 protein and function, demonstrating a critical role for TrkB activation in activity-dependent downregulation of KCC2. Thus, the BDNF-triggered activation of calpain may contribute to the activity-induced and BDNF/TrkBmediated downregulation of KCC2.

As shown by our electrophysiological data, calpain-mediated cleavage results in near complete loss of KCC2-mediated $\mathrm{Cl}^{-}$ extrusion (Fig. 5). However, the biochemical data (Fig. 4) indicate that a fraction of KCC2 is resistant to calpain within the time window of the present experiments. Curiously, BDNF-calpain signaling has been proposed to regulate spine plasticity (Zadran et al., 2010a). Since spines are known to express high levels of KCC2 (cf. Gulyas et al., 2001), the effects of calpain activation on KCC2-related spinogenesis (Fiumelli et al., 2012) and spine maintenance (Li et al., 2007) emerge as important topics for future research.

In conclusion, this work shows that fast, activity-dependent downregulation of KCC2 is attributable to calpain-mediated cleavage of the protein and not to suppression of KCC2 gene expression. It thereby identifies a new molecular mechanism for the fast regulation of KCC2 during synaptic plasticity under physiological and pathophysiological conditions.

\section{References}

Acton BA, Mahadevan V, Mercado A, Uvarov P, Ding Y, Pressey J, Airaksinen MS, Mount DB, Woodin MA (2012) Hyperpolarizing GABAergic transmission requires the KCC2 C-terminal ISO domain. J Neurosci 32:8746-8751.

Ahmad F, Coleman SK, Kaila K, Blaesse P (2011) Surface expression analysis: a protease cleavage approach using cold-adapted trypsin. Biotechniques 50:255-257.

Anderson WW, Lewis DV, Swartzwelder HS, Wilson WA (1986) Magnesium-free medium activates seizure-like events in the rat hippocampal slice. Brain Res 398:215-219.

Baliova M, Jursky F (2005) Calpain sensitive regions in the N-terminal cytoplasmic domains of glycine transporters GlyT1A and GlyT1B. Neurochem Res 30:1093-1100.

Baliova M, Betz H, Jursky F (2004) Calpain-mediated proteolytic cleavage of the neuronal glycine transporter, GlyT2. J Neurochem 88:227-232.

Bano D, Young KW, Guerin CJ, Lefeuvre R, Rothwell NJ, Naldini L, Rizzuto R, Carafoli E, Nicotera P (2005) Cleavage of the plasma membrane $\mathrm{Na}^{+} / \mathrm{Ca}^{2+}$ exchanger in excitotoxicity. Cell 120:275-285.

Barry PH (1994) JPCalc, a software package for calculating liquid junction potential corrections in patch-clamp, intracellular, epithelial and bilayer measurements and for correcting junction potential measurements. J Neurosci Methods 51:107-116.

Bi X, Chen J, Baudry M (1997) Developmental changes in calpain activity,
GluR1 receptors and in the effect of kainic acid treatment in rat brain. Neuroscience 81:1123-1135.

Binder DK, Croll SD, Gall CM, Scharfman HE (2001) BDNF and epilepsy: too much of a good thing? Trends Neurosci 24:47-53.

Bingol B, Sheng M (2011) Deconstruction for reconstruction: the role of proteolysis in neural plasticity and disease. Neuron 69:22-32.

Blaesse P, Guillemin I, Schindler J, Schweizer M, Delpire E, Khiroug L, Friauf E, Nothwang HG (2006) Oligomerization of KCC2 correlates with development of inhibitory neurotransmission. J Neurosci 26:10407-10419.

Blaesse P, Airaksinen MS, Rivera C, Kaila K (2009) Cation-chloride cotransporters and neuronal function. Neuron 61:820-838.

Buddhala C, Suarez M, Modi J, Prentice H, Ma Z, Tao R, Wu JY (2012) Calpain cleavage of brain glutamic acid decarboxylase 65 is pathological and impairs GABA neurotransmission. PLoS One 7:e33002.

Cui G, Dean WL, Delamere NA (2002) The influence of cycloheximide on $\mathrm{Na}, \mathrm{K}-\mathrm{ATP} a \mathrm{se}$ activity in cultured human lens epithelial cells. Invest Ophthalmol Vis Sci 43:2714-2720.

Denny JB, Polan-Curtain J, Ghuman A, Wayner MJ, Armstrong DL (1990) Calpain inhibitors block long-term potentiation. Brain Res 534:317-320.

Dong YN, Waxman EA, Lynch DR (2004) Interactions of postsynaptic density-95 and the NMDA receptor 2 subunit control calpain-mediated cleavage of the NMDA receptor. J Neurosci 24:11035-11045.

Farrant M, Kaila K (2007) The cellular, molecular and ionic basis of GABAA receptor signalling. Prog Brain Res 160:59-87.

Feng ZH, Hao J, Ye L, Dayao C, Yan N, Yan Y, Chu L, Shi FD (2011) Overexpression of mu-calpain in the anterior temporal neocortex of patients with intractable epilepsy correlates with clinicopathological characteristics. Seizure 20:395-401.

Fiumelli H, Cancedda L, Poo MM (2005) Modulation of GABAergic transmission by activity via postsynaptic $\mathrm{Ca}^{2+}$-dependent regulation of KCC2 function. Neuron 48:773-786.

Fiumelli H, Briner A, Puskarjov M, Blaesse P, Belem BJ, Dayer AG, Kaila K, Martin JL, Vutskits L (2012) An ion transport-independent role for the cation-chloride cotransporter KCC2 in dendritic spinogenesis in vivo. Cereb Cortex. Advance online publication. Retrieved February 17, 2012. doi:10.1093/cercor/bhs027.

Fujikawa DG (2005) Prolonged seizures and cellular injury: understanding the connection. Epilepsy Behav 7 Suppl 3:S3-S11.

Gascón S, Sobrado M, Roda JM, Rodríguez-Peña A, Díaz-Guerra M (2008) Excitotoxicity and focal cerebral ischemia induce truncation of the NR2A and NR2B subunits of the NMDA receptor and cleavage of the scaffolding protein PSD-95. Mol Psychiatry 13:99-114.

Gauvain G, Chamma I, Chevy Q, Cabezas C, Irinopoulou T, Bodrug N, Carnaud M, Lévi S, Poncer JC (2011) The neuronal K-Cl cotransporter KCC2 influences postsynaptic AMPA receptor content and lateral diffusion in dendritic spines. Proc Natl Acad Sci U S A 108:15474-15479.

Gil-Parrado S, Fernández-Montalván A, Assfalg-Machleidt I, Popp O, Bestvater F, Holloschi A, Knoch TA, Auerswald EA, Welsh K, Reed JC, Fritz H, Fuentes-Prior P, Spiess E, Salvesen GS, Machleidt W (2002) Ionomycinactivated calpain triggers apoptosis. A probable role for Bcl-2 family members. J Biol Chem 277:27217-27226.

Gomes JR, Lobo AC, Melo CV, Inácio AR, Takano J, Iwata N, Saido TC, de Almeida LP, Wieloch T, Duarte CB (2011) Cleavage of the vesicular GABA transporter under excitotoxic conditions is followed by accumulation of the truncated transporter in nonsynaptic sites. J Neurosci 31:4622-4635.

Gulyás AI, Sík A, Payne JA, Kaila K, Freund TF (2001) The KCI cotransporter, $\mathrm{KCC} 2$, is highly expressed in the vicinity of excitatory synapses in the rat hippocampus. Eur J Neurosci 13:2205-2217.

Huberfeld G, Wittner L, Clemenceau S, Baulac M, Kaila K, Miles R, Rivera C (2007) Perturbed chloride homeostasis and GABAergic signaling in human temporal lobe epilepsy. J Neurosci 27:9866-9873.

Hübner CA, Stein V, Hermans-Borgmeyer I, Meyer T, Ballanyi K, Jentsch T] (2001) Disruption of KCC2 reveals an essential role of K-Cl cotransport already in early synaptic inhibition. Neuron 30:515-524.

Jarolimek W, Lewen A, Misgeld U (1999) A furosemide-sensitive K+-Clcotransporter counteracts intracellular $\mathrm{Cl}$ - accumulation and depletion in cultured rat midbrain neurons. J Neurosci 19:4695-4704.

Kampfl A, Posmantur RM, Zhao X, Schmutzhard E, Clifton GL, Hayes RL (1997) Mechanisms of calpain proteolysis following traumatic brain injury: implications for pathology and therapy: implications for pathology and therapy: a review and update. J Neurotrauma 14:121-134. 
Khalilov I, Chazal G, Chudotvorova I, Pellegrino C, Corby S, Ferrand N, Gubkina O, Nardou R, Tyzio R, Yamamoto S, Jentsch TJ, Hübner CA, Gaiarsa JL, Ben-Ari Y, Medina I (2011) Enhanced synaptic activity and epileptiform events in the embryonic KCC2 deficient hippocampus. Front Cell Neurosci 5:23.

Khirug S, Huttu K, Ludwig A, Smirnov S, Voipio J, Rivera C, Kaila K, Khiroug L (2005) Distinct properties of functional KCC2 expression in immature mouse hippocampal neurons in culture and in acute slices. Eur J Neurosci 21:899-904.

Khirug S, Yamada J, Afzalov R, Voipio J, Khiroug L, Kaila K (2008) GABAergic depolarization of the axon initial segment in cortical principal neurons is caused by the $\mathrm{Na}-\mathrm{K}-2 \mathrm{Cl}$ cotransporter NKCC1. J Neurosci 28:4635-4639.

Khirug S, Ahmad F, Puskarjov M, Afzalov R, Kaila K, Blaesse P (2010) A single seizure episode leads to rapid functional activation of KCC2 in the neonatal rat hippocampus. J Neurosci 30:12028-12035.

Kneussel M, Betz H (2000) Clustering of inhibitory neurotransmitter receptors at developing postsynaptic sites: the membrane activation model. Trends Neurosci 23:429-435.

Lee HH, Jurd R, Moss SJ (2010) Tyrosine phosphorylation regulates the membrane trafficking of the potassium chloride co-transporter KCC2. Mol Cell Neurosci 45:173-179.

Lee HH, Deeb TZ, Walker JA, Davies PA, Moss SJ (2011) NMDA receptor activity downregulates KCC2 resulting in depolarizing GABAA receptormediated currents. Nat Neurosci 14:736-743.

Li H, Khirug S, Cai C, Ludwig A, Blaesse P, Kolikova J, Afzalov R, Coleman SK, Lauri S, Airaksinen MS, Keinänen K, Khiroug L, Saarma M, Kaila K, Rivera C (2007) KCC2 interacts with the dendritic cytoskeleton to promote spine development. Neuron 56:1019-1033.

Liu J, Liu MC, Wang KK (2008) Calpain in the CNS: from synaptic function to neurotoxicity. Sci Signal 1:re1.

Löscher W, Puskarjov M, Kaila K (2012) Cation-chloride cotransporters $\mathrm{NKCC} 1$ and KCC2 as potential targets for novel antiepileptic and antiepileptogenic treatments. Neuropharmacology. In press.

Ludwig A, Li H, Saarma M, Kaila K, Rivera C (2003) Developmental upregulation of KCC2 in the absence of GABAergic and glutamatergic transmission. Eur J Neurosci 18:3199-3206.

Lynch G, Baudry M (1984) The biochemistry of memory: a new and specific hypothesis. Science 224:1057-1063.

Mercado A, Broumand V, Zandi-Nejad K, Enck AH, Mount DB (2006) A C-terminal domain in $\mathrm{KCC} 2$ confers constitutive $\mathrm{K}^{+}{ }_{-} \mathrm{Cl}^{-}$cotransport. J Biol Chem 281:1016-1026.

Mody I, Lambert JD, Heinemann U (1987) Low extracellular magnesium induces epileptiform activity and spreading depression in rat hippocampal slices. J Neurophysiol 57:869-888.

Nixon RA (1986) Fodrin degradation by calcium-activated neutral proteinase (CANP) in retinal ganglion cell neurons and optic glia: preferential localization of CANP activities in neurons. J Neurosci 6:1264-1271.

Payne JA, Rivera C, Voipio J, Kaila K (2003) Cation-chloride co-transporters in neuronal communication, development and trauma. Trends Neurosci 26:199-206.

Piper RC, Luzio JP (2007) Ubiquitin-dependent sorting of integral membrane proteins for degradation in lysosomes. Curr Opin Cell Biol 19:459-465.

Pottorf WJ 2nd, Johanns TM, Derrington SM, Strehler EE, Enyedi A, Thayer SA (2006) Glutamate-induced protease-mediated loss of plasma membrane $\mathrm{Ca}^{2+}$ pump activity in rat hippocampal neurons. J Neurochem 98:1646-1656.

Rechsteiner M, Rogers SW (1996) PEST sequences and regulation by proteolysis. Trends Biochem Sci 21:267-271.

Rivera C, Voipio J, Payne JA, Ruusuvuori E, Lahtinen H, Lamsa K, Pirvola U, Saarma M, Kaila K (1999) The $\mathrm{K}+/ \mathrm{Cl}^{-}$co-transporter $\mathrm{KCC} 2$ renders GABA hyperpolarizing during neuronal maturation. Nature 397:251-255.

Rivera C, Li H, Thomas-Crusells J, Lahtinen H, Viitanen T, Nanobashvili A, Kokaia Z, Airaksinen MS, Voipio J, Kaila K, Saarma M (2002) BDNFinduced TrkB activation down-regulates the $\mathrm{K}^{+}-\mathrm{Cl}^{-}$cotransporter KCC2 and impairs neuronal $\mathrm{Cl}^{-}$extrusion. J Cell Biol 159:747-752.

Rivera C, Voipio J, Thomas-Crusells J, Li H, Emri Z, Sipilä S, Payne JA,
Minichiello L, Saarma M, Kaila K (2004) Mechanism of activitydependent downregulation of the neuron-specific $\mathrm{K}-\mathrm{Cl}$ cotransporter KCC2. J Neurosci 24:4683-4691.

Schafer DP, Jha S, Liu F, Akella T, McCullough LD, Rasband MN (2009) Disruption of the axon initial segment cytoskeleton is a new mechanism for neuronal injury. J Neurosci 29:13242-13254.

Seglen PO, Grinde B, Solheim AE (1979) Inhibition of the lysosomal pathway of protein degradation in isolated rat hepatocytes by ammonia, methylamine, chloroquine and leupeptin. Eur J Biochem 95:215-225.

Sha D, Jin Y, Wu H, Wei J, Lin CH, Lee YH, Buddhala C, Kuchay S, Chishti $\mathrm{AH}, \mathrm{Wu}$ JY (2008) Role of mu-calpain in proteolytic cleavage of brain L-glutamic acid decarboxylase. Brain Res 1207:9-18.

Sierra-Paredes G, Cornes JM, Sierra-Marcuño G (1999) Calpain inhibitor I retards seizure offset in the hippocampus of freely moving rats. Neurosci Lett 263:165-168.

Siman R, Noszek JC (1988) Excitatory amino acids activate calpain I and induce structural protein breakdown in vivo. Neuron 1:279-287.

Siman R, Baudry M, Lynch G (1984) Brain fodrin: substrate for calpain I, an endogenous calcium-activated protease. Proc Natl Acad Sci USA 81:3572-3576.

Siman R, Noszek JC, Kegerise C (1989) Calpain I activation is specifically related to excitatory amino acid induction of hippocampal damage. J Neurosci 9:1579-1590.

Stockholm D, Bartoli M, Sillon G, Bourg N, Davoust J, Richard I (2005) Imaging calpain protease activity by multiphoton FRET in living mice. J Mol Biol 346:215-222.

Thomas-Crusells J, Vieira A, Saarma M, Rivera C (2003) A novel method for monitoring surface membrane trafficking on hippocampal acute slice preparation. J Neurosci Methods 125:159-166.

Tyagarajan SK, Ghosh H, Yéveness GE, Nikonenko I, Ebeling C, Schwerdel C, Sidler C, Zeilhofer HU, Gerrits B, Muller D, Fritschy JM (2011) Regulation of GABAergic synapse formation and plasticity by GSK3betadependent phosphorylation of gephyrin. Proc Natl Acad Sci U S A 108:379-384.

Villa PG, Henzel WJ, Sensenbrenner M, Henderson CE, Pettmann B (1998) Calpain inhibitors, but not caspase inhibitors, prevent actin proteolysis and DNA fragmentation during apoptosis. J Cell Sci 111:713-722.

von Reyn CR, Spaethling JM, Mesfin MN, Ma M, Neumar RW, Smith DH, Siman R, Meaney DF (2009) Calpain mediates proteolysis of the voltage-gated sodium channel alpha-subunit. J Neurosci 29:10350-10356.

Wake H, Watanabe M, Moorhouse AJ, Kanematsu T, Horibe S, Matsukawa N, Asai K, Ojika K, Hirata M, Nabekura J (2007) Early changes in KCC2 phosphorylation in response to neuronal stress result in functional downregulation. J Neurosci 27:1642-1650.

Wang N, Chen W, Linsel-Nitschke P, Martinez LO, Agerholm-Larsen B, Silver DL, Tall AR (2003) A PEST sequence in ABCA1 regulates degradation by calpain protease and stabilization of ABCA1 by apoA-I. J Clin Invest 111:99-107.

Wei J, Lin CH, Wu H, Jin Y, Lee YH, Wu JY (2006) Activity-dependent cleavage of brain glutamic acid decarboxylase 65 by calpain. J Neurochem 98:1688-1695.

Wu HY, Lynch DR (2006) Calpain and synaptic function. Mol Neurobiol $33: 215-236$

Xu W, Wong TP, Chery N, Gaertner T, Wang YT, Baudry M (2007) Calpain-mediated mGluRlalpha truncation: a key step in excitotoxicity. Neuron 53:399-412.

Zadran S, Jourdi H, Rostamiani K, Qin Q, Bi X, Baudry M (2010a) Brainderived neurotrophic factor and epidermal growth factor activate neuronal $\mathrm{m}$-calpain via mitogen-activated protein kinase-dependent phosphorylation. J Neurosci 30:1086-1095.

Zadran S, Bi X, Baudry M (2010b) Regulation of calpain-2 in neurons: implications for synaptic plasticity. Mol Neurobiol 42:143-150.

Zhang W, Lane RD, Mellgren RL (1996) The major calpain isozymes are long-lived proteins. Design of an antisense strategy for calpain depletion in cultured cells. J Biol Chem 271:18825-18830.

Zhou M, Baudry M (2006) Developmental changes in NMDA neurotoxicity reflect developmental changes in subunit composition of NMDA receptors. J Neurosci 26:2956-2963. 